ISSN: 2146-3042

DOI: $10.25095 /$ mufad.465900

\title{
IFRS 16 Kapsamında Kiralama İşlemlerinin Finansal Raporlamaya Etkisinin İncelenmesi
}

Beyhan MARŞAP*

Serap YANIK **

\section{ÖZET}

Şirketler finansal ve faaliyet kiralaması olmak üzere iki tür kiralama yapmaktadırlar. Mevcut durumda finansal kiralama borçları ve alacakları finansal raporlarda yer alırken faaliyet kiralamalarından doğan borç ve alacaklar yer almamaktadır. Finansal risk yönetimi açısından bu durum değerlendirildiğinde, özellikle kiracı şirketlerin birçoğu finansal raporlarında gösterilenden daha fazla riski bilanço dışına taşımaktadırlar. Bu sebeple birçok yatırımcı ve analistin, bilanço dışı kalan bu kiralamalardan kaynaklanan varlık ve yükümlülüklerin finansal raporlar üzerindeki etkisini görmek amacılla kiracının finansal raporlarındaki tutarları düzeltmesi gerekmektedir. Diğer taraftan finansal raporların şeffaflı̆̆l, karşılaştırlabilirliği ve gerçeğe uygun sunumunu sağlamak için dünyada 10 yıldan bu yana bu konu tartışılmıştır. Sonuç olarak kiralama standardl, Uluslararası Muhasebe Standartlarl Kurulu (IASB) tarafindan 1 Ocak 2019 tarihinden itibaren uygulanmak üzere, Ocak 2016'da yayımlanmıştır. Türkiye'de ise Kamu Gözetimi Kurumu (KGK) Şubat 2017'de "TFRS16 Kiralamalar" taslak metnini kamuoyu görüşüne sunmuş, nihai metin ise 31.12.2018 tarihinden sonra başlayan hesap dönemlerinde uygulanmak üzere 16 Nisan 2018 tarihinde yürürlüğe girmiştir. Bu çallşmada kiralama işlemlerinin muhasebeleştirme, ölçüm ve finansal raporlamaya etkisi, IFRS 16 kapsaminda irdelenecektir.

Anahtar Kelimeler: IFRS 16, finansal raporlama, finansal kiralama, faaliyet kiralamasi

JEL Sinıflandirması: M40, M41, M48

\section{Examining the Effect of Leasing Transactions on Financial Reporting Within the Scope of IFRS 16}

\section{ABSTRACT}

As is known, companies make two types of leases, financial leasing and operating lease. Currently, Finance lease payables and receivables are included in the financial statements while debts and receivables arising from operating leases are not included. When assessed in terms of financial risk management, most of the tenant companies, especially those listed in the financial statements, carry more of the risk off balance sheet. On the other hand, this issue has been discussed in the world for over 10 years to ensure transparency and comparability of financial reports and to provide a fair presentation and the leasing standard has been issued by the International Accounting Standards Board (IASB) for adoption from January 2016 onwards as of January 2019. In Turkey, Public Oversight, Accounting and Auditing Standards Authority (KGK) submitted the draft TFRS16 on February 2017 to the public opinion. The final text, TFRS 16 Leases, entered into force on April 16, 2018, to be applied for the fiscal periods beginning after 31.12.2018. In this study, the measurement, recognition and financial reporting of leasing transactions is examined within the scope of IRRS 16.

Keywords: IFRS 16, financial reporting, financial leasing, operating lease.

Jel Classification: M40, M41, M48

\footnotetext{
* Prof. Dr. Beyhan Marşap, Ankara Hacı Bayram Veli Üniversitesi, İktisadi ve İdari Bilimler Fakültesi, bguclu@gazi.edu.tr

${ }^{* *}$ Prof. Dr. Serap Yanık, Ankara Hacı Bayram Veli Üniversitesi, İktisadi ve İdari Bilimler Fakültesi, seraps@gazi.edu.tr
} 


\section{GíRiş}

Kiralama işlemleri, kısa vadeli varlık kullanımından uzun vadeli varlık finansmanına kadar çeşitli işletme ihtiyaçlarını karşılamak için yaygın bir şekilde kullanılmaktadır. Özellikle bazı fiziksel varlıkların örneğin bir alışveriş merkezindeki tek bir mağazanın kullanım hakkını elde etmek için kiralama yoluna gitmek bazen tek seçenek olabilir. İşletmeler faaliyet kiralaması olarak da ifade edilen bu tür kiralamalar yoluyla bilanço dışı bir finansman kaynağı sağlamaktadırlar. Bu durum (IASB-Uluslararası Muhasebe Standartları Kurulu ve FASB-Finansal Muhasebe Standartları Kurulu tarafindan yayınlanan) mevcut standartlarda yer alan hükümlerin (uygulanan muhasebe modelinin) yetersizliği yönünde eleştirilere neden olmuştur.

IASB ve FASB, mevcut yaklaşımla ilgili endişeleri gidermek için küresel çapta yakınsama uygulamalarının bir parçası olarak 2006'da kiralama üzerine ortak bir proje başlatmış, eleştirileri dikkate alarak standart taslağ sonucunda IASB 13 Ocak 2016 (IFRS 16 Kiralama) ve FASB 25 Şubat 2016 (FASB ASC 842 Kiralama) tarihlerinde önemli alanlarda farklılık gösteren ayrı ayrı kiralama standartları yayınlamışlardır (FASB-Lease-Accounting-Handbook-2016).

IFRS 16 ve FASB ASC 842 standartları 1 Ocak 2019 tarihinde veya sonrasında başlayan yıllık raporlama dönemlerinde uygulanacak olup TFRS 15 Müşteri Sözleşmelerinden Hasılat'1 uygulayan işletmeler için erken uygulamaya izin verilmiştir. Erken uygulama halinde, bu husus dipnotlarda açıklanmalıdır.

Türkiye'de ise Kamu Gözetimi Kurumu (KGK) Şubat 2017'de "TFRS16 Kiralamalar" taslak metnini kamuoyu görüşüne sunmuştur. Nihai metin olan TFRS 16 Kiralamalar Standard1, 31.12.2018 tarihinden sonra başlayan hesap dönemlerinde uygulanmak üzere 16 Nisan 2018 tarihinde yürürlüğe girmiştir.

Kiralama standardının IASB tarafından taslak metninin yayınlanması sürecinden KGK dahil nihai metne kadar TFRS 16 standardının muhtemel etkilerine yönelik literatürde çeşitli çalışmalar yer almıştır. Bu çalışmalarda özellikle kiracı açısından yeni standardın etkileri incelenmiştir (Öztürk, 2016; Acar vd., 2017; Aktaş vd., 2017; Aslan 2018; Czajor ve Michalak, 2017; Morales-Díaz ve Zamora-Ramírez, 2018; Joubert vd., 2017; Akbulut, 2018).

\section{KİRALAMANIN TANIMLANMASI}

Kiralama, bir bedel karşılığında, tanımlanan bir varlığın kullanımını kontrol etme hakkını belirli bir süre için bir başkasına devretme olarak tanımlanabilir (TFRS 16 Ek A). Diğer bir ifadeyle bir sözleşme, bir bedel karşılığında ve belirli bir süre için bir varlığın kullanımını kontrol etme hakkını bir başkasına devretmeyi içeren hükümler taşıyorsa bu sözleşme bir kiralama sözleşmesidir.

İşletmenin, sözleşmenin kiralama niteliği taşıyıp taşımadığını ya da kiralama işlemi içerip içermediğini değerlendirmesi gerekmektedir. Kiralama işlemi içeren bir sözleşme aşağıdaki unsurların ikisini bir arada taşımalıdır (TFRS 16 Ek B9): 
a) Tanımlanan varlı̆̆ın kullanımından sağlanacak ekonomik yararların tamamına yakınını elde etme hakkı: İşletme varlığı kullanma, elde tutma veya alt kiralamayla başkalarına kiraya verme gibi birçok yolla doğrudan veya dolaylı olarak bu yararı elde edebilir. Burada varlığın kullanma hakkının tanımlanmış kapsamı dâhilinde kullanımından sağlanan ekonomik yararlar dikkate alınmalıdır (TFRS 16 B21, B22)

b) Tanımlanan varlığın kullanımını yönetme hakkı: Kiracı önceden veya kullanım süresi boyunca varlığın nasıl ve ne amaçla kullanılacağını örneğin, bir nakliye konteynırının mal taşıma amacıyla mı yoksa depolama amacıyla mı kullanılacağına önceden karar vermeli ve bu varlığı yönetme hakkına sahip olmalıdır (TFRS 16 B24, B26).

Kiraya verenin kiralanan varlıkla ilgili ikame etme hakkı var ise kiracının varlığ yönetme hakkı konusunda değerlendirme yapmak gerekmektedir. Bununla birlikte belirli bir tarihte veya belirlenen bir olay meydana geldiğinde tedarikçinin başka bir varlık ikame etme hakkına sahip olması, ikame hakkının aslî olduğunu göstermez. Tedarikçinin aslî ikame hakkına sahip olup olmadığının kolayca tespit edilememesi durumunda müşteri, ikame haklarının aslî olmadığını varsayar. Aynı şekilde varlığın düzgün çalışmaması veya teknik bir yükseltmenin mevcut olması durumunda, tedarikçinin varlığın tamiri ve bakımı için varlığı ikame etme hak veya yükümlülüğü, müşterinin tanımlanan varlığın kullanım hakkına sahip olmasinı engellemez (TFRS 16 B15, B18, B19).

Örnek 1 (illustrative exampledan uyarlanmıştır): Bir müşteri, İstanbul'dan Ankara'ya kargo taşımak üzere bir haftalığına kamyon kiralamak için tedarikçi ile bir sözleşme imzalamıştır. Tedarikçinin ikame haklarının olmadiğl sözleşmede belirtilen kargonun sözleşme süresi boyunca bu araçta taşınmasına izin verilmektedir. Sözleşmede, kamyonun gidebileceği maksimum mesafe yer almaktadır. Müşteri, sözleşmenin parametreleri dahilinde yolculuğun ayrıntılarını (hız, rota, mola, vb.) seçebilme hakkına sahiptir. Müşteri, belirtilen seyahat bittikten sonra kamyonu kullanmaya devam etme hakkına sahip değildir. Sözleşmede; taşınacak kargo, Istanbul'dan kalkış yeri ve zamanı ile teslimat yeri belirtilmişstir. Müşteri, kamyonun İstanbul'dan Ankara'ya kadar kullanılmasindan sorumludur.

Çözüm: Sözleşme kamyonun kiralanmasını içermektedir. Bu kiralama aynı zamanda kısa vadeli bir kiralamadır. Müşteri, belirtilen seyahat süresince kamyonu kullanma hakkına sahiptir. Sözleşmede tanımlanmış bir varlık bulunmaktadır. Kamyon sözleşmede açıkça belirtilmiş olup, tedarikçi kamyonu değiştirme hakkına sahip değildir.

Müşteri, bir hafta boyunca aracın kullanımını kontrol etme hakkına sahiptir. Çünkü:

(a) Müşteri, kullanım süresince aracın kullanımından kaynaklanan tüm ekonomik faydaları büyük ölçüde elde etme hakkına sahiptir. Müşteri, kullanım süresi boyunca kamyonu tek başına kullanmaktadır.

(b) Müşterinin aracın kullanımını yönlendirmesi hakkı vardır. Kamyonun hangi amaçla kullanılacağı (belirli bir süre içerisinde İstanbul'dan Ankara'ya belirli bir kargonun taşınması) sözleşmede önceden belirlenmiştir. Müşteri, kullanım süresince kamyonu

(örneğin hız, yol, mola gibi) çalıştırma hakkına sahip olduğu için kamyonun kullanımını yönlendirebilmektedir. Müşteri, kamyonun kontrolü ile kullanım süresi boyunca yapılabilecek işlemlerle ilgili tüm kararları alabilmektedir. 


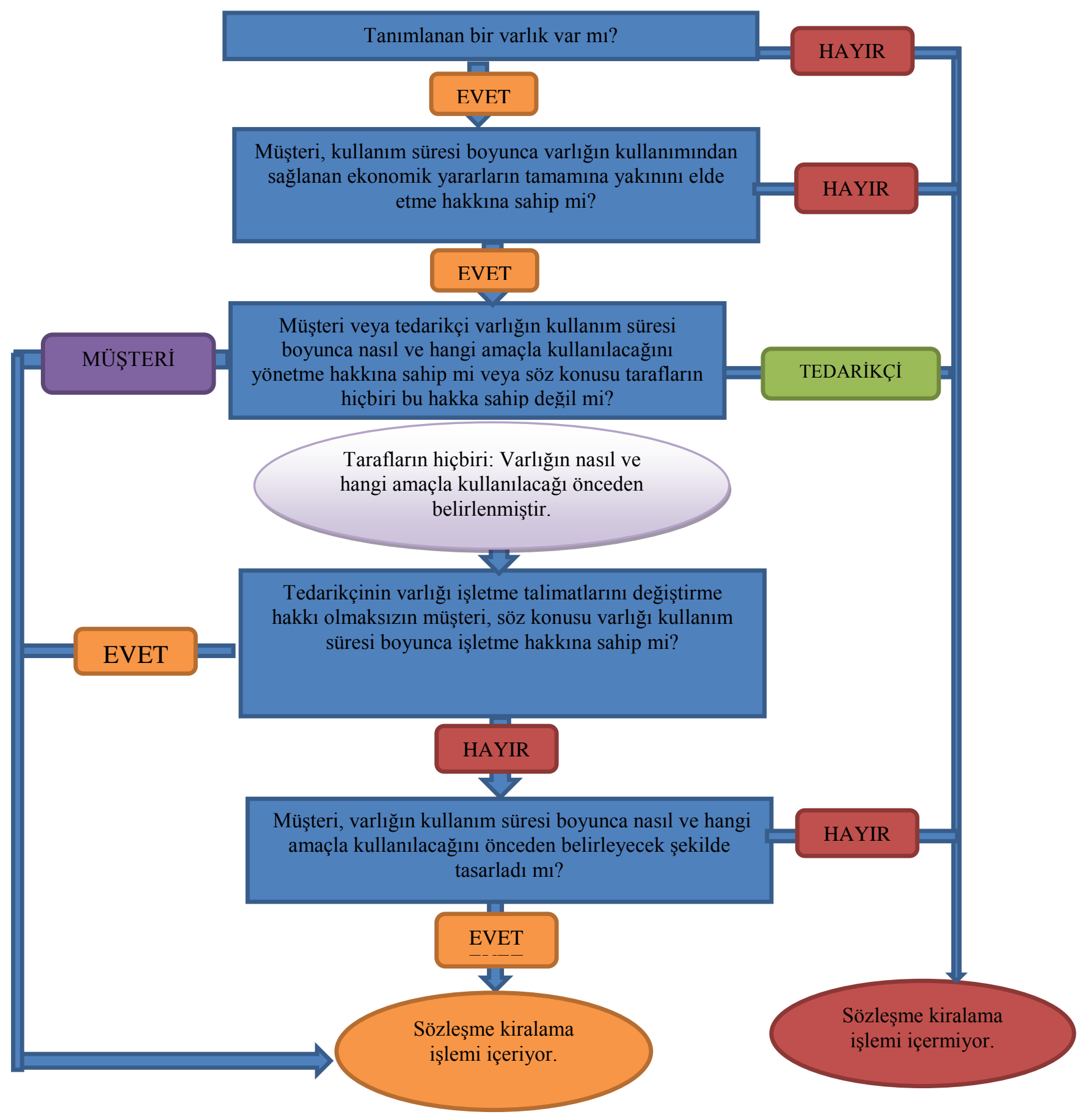

Şekil 1. Bir Kiralama Sözleşmesinin Belirlenmesi (Kaynak: TFRS 16 B31) 


\subsection{Kiralamanın Unsurları}

Kiralama işleminin unsurları; tanımlanan varlığın belirlenmesi, kullanımı kontrol etme hakk1, belirli bir kira süresi ve kira bedelidir.

\subsubsection{Tanımlanan Varlığın Belirlenmesi}

Sözleşmede kiraya konu varlığın da tanımlanması önem arz etmektedir. Bir varlık genellikle sözleşmede açık bir şekilde belirtilerek tanımlanır. Bununla birlikte, bir varlık müşterinin kullanımına sunulduğunda zımnen belirtilerek de tanımlanabilir ( TFRS 16 Ek B13). Sözleşmede bir varlık belirlenmiş olsa dahi, tedarikçinin sözleşmede belirtilen varlığ kullanım süresi içerisinde başka bir varlıkla ikame etme hakkı varsa ve bu ikameden ekonomik bir yarar sağlama durumu söz konusu ise tedarikçi varlığı ikame etme yönünde aslî bir hakka sahip olduğu için müşteri, tanımlanan varlığı kullanma hakkına sahip değildir.

Örnek 2 (illustrative exampledan uyarlanmıştır): Bir kahve şirketi (Müşteri) havaalanında ürünlerini üç yıllık bir süre için satacak bir yer alan bulmak üzere TAV şirketi ile (havaalanı işletmecisi) bir sözleşme imzalamıştır (Tedarikçi). Sözleşmede, kiralanacak alanın metrekaresi ve kiralanacak yerin havaalanindaki kapılardan (boarding) herhangi birine yakın yerde bulunabileceği belirtilmiştir. Tedarikçi, kullanım süresi boyunca herhangi bir zamanda müşteriye tahsis edilen alanın yerini değiştirme hakkına sahiptir. Havaalanında mevcut olan ve sözleşmedeki alanın özelliklerini karşılayan birçok alan bulunmaktadır. Müşteri, ürünlerini satmak için kolaylıkla taşınabilen bir büfe kullanmaktadır. Bu nedenle tedarikçinin müşterinin alanını değiştirmeyle ilişkili çok az bir maliyeti bulunmaktadır.

Çözüm: Müşteri kendi büfesini denetleyebilmesine ve müşterinin kullandığı alanın $\mathrm{m}^{2}$ si sözleşmede belirtilmesine rağmen tedarikçinin müşterinin kullandığı alanı değiştirme hakkına sahip olması nedeniyle tanımlanmış bir varlık olmadı̆̆ için sözleşme bir kiralama içermemektedir (TFRS 16 Ek B14). Çünkü sözleşme havaalanındaki yerlerden herhangi bir alan için olup bu alan tedarikçinin takdirine bağlı olarak müşterinin kullanım süresi boyunca kullandığı alanı değiştirme hakkına sahiptir. Havalimanında sözleşmedeki alanın özelliklerini karşılayan birçok alan vardır ve tedarikçi alanın yerini, müşterinin onayı olmaksızın istediği zaman, özelliklere uygun olan diğer alanlara değiştirme hakkına sahiptir. Aynı zamanda tedarikçi, alanın yerini değiştirdiğinde ekonomik olarak fayda sağlayacaktır. Büfe kolayca taşınabileceğinden, müşteri tarafından kullanılan alanı değiştirmeyle ilgili tedarikçiye maliyeti minimum olacaktır. Tedarikçinin bu şekillerde yer değiştirme hakkına sahip olması, alanlardan daha iyi yararlanmasına imkân tanımaktadır.

\subsubsection{Tanımlanan Varlığı Kontrol Etme Hakkı}

Bir kiralama işleminde tanımlanan bir varlığın kontrol edilebilir olup olmadığı, sözleşmenin bir kiralama içerip içermediğini belirlemede önemli bir unsurdur. Kontrol, tanımlanan varlığın kullanımından sağlanacak ekonomik yararların tamamına yakınını elde etme ve tanımlanan varlığın kullanımını yönetme hakkına sahip olma ile ölçülmektedir. Müşterinin, sözleşme süresinin yalnızca bir kısmı boyunca tanımlanan varlığın kullanımını kontrol etme hakkına sahip olması durumunda, sözleşmenin sadece sürenin o kısmı için bir kiralama söz konusudur ( TFRS 16 B10). Yine aynı şekilde bir müşterek anlaşma sözleşmesinin bir varlık veya hizmet alımına yönelik bir sözleşme yapması durumunda, bu 
sözleşmenin kiralama içerip içermediğinin değerlendirilmesinde, işletme, kullanım süresi boyunca müşterek anlaşmanın tanımlanan varlığın kullanımını kontrol etme hakkına sahip olup olmadığını değerlendirmelidir.

\subsubsection{Kiralama Süresi}

Kiracının kiralamaya konu varlığı kullanma hakkına sahip olduğu süre iptal edilemeyen kiralama süresi olarak ifade edilmektedir. Bir kira sözleşmesinde kira süresinin sonunda üç farklı opsiyon bulunmaktadır. Bunlar kiraya konu varlığı;

i. Satın alma

ii. Kiralamayı uzatma ve

iii. Kiralamayı sonlandırmama.

Dolayısıyla kiralama süresinin belirlenmesinde kiracının kiralamayı uzatma ve sonlandırma hakkını veren opsiyonları kullanıp kullanmayacağı da önem arz etmektedir.

Kiracının kiralamayı uzatma hakkı veren bir opsiyonu kullanacağından ve kiralamayı sonlandırma hakkı veren bir opsiyonu kullanmayacağından makul ölçüde emin olunması durumlarında kira süresine bu opsiyonlar da eklenmektedir (TFRS 16 md. 18, Ek A).

Kiralama süresi sadece zaman esaslı değil miktar esaslı olarak da belirlenebilir. Tanımlanan varlığın kullanım miktarı örneğin, bir teçhizat kullanılarak üretilecek olan üretim birimlerinin sayısı da kiralama süresi olarak belirlenebilmektedir (TFRS 16 md. 10).

İşletme kiracının kiralanan varlıkla ilgili opsiyonlarını kullanıp kullanmayacağı ile ilgili kira döneminin başlangıcında makul ölçüde emin olup olmadığını değerlendirir. Bu aşamada kiracı açısından ekonomik teşvik oluşturan durumları göz önünde bulundurmalı ve buna göre kira başlangıç tarihinde, piyasa fiyatlarını, kiracıya ekonomik yarar sağlayan önemli teşvikleri, kiralamanın sonlandırılmasıyla ilgili maliyetleri, varlığın özel amaçlı bir varlık olup olmadığını vb. durumları değerlendirmelidir. Kira süresi kısaldıkça kiracının opsiyonları değerlendirme ihtimali artacaktır (TFRS 16 md. 18-21, Ek B37-40).

Kiralama süresi kiralamanın fiilen başladığı tarihte başlar ve kiraya verenin kiracıya sağladığı tüm bedelsiz kiralama sürelerini kapsar. Kiralama süresi, kiracının sözleşme dışı bir opsiyonu kullanması veya kullanmak durumunda kalması durumunda değişebilmektedir. Örneğin, iptal edilemez kiralama süresi

i. işletmenin daha önce kiralama süresini belirlerken dikkate almadığ opsiyonu sözleşme gereği kiracının kullanmasını zorunlu tutan bir olayın meydana gelmesi veya

ii. veya işletmenin daha önce kiralama süresini belirlerken dikkate aldığı bir opsiyonu sözleşme gereği kiracının kullanmasını engelleyen bir olayın meydana gelmesi

gibi durumlarda işletme, iptal edilemez kiralama süresinde değişiklik yapmak durumunda kalabilir. 


\subsubsection{Kira Bedeli Ödemeleri}

Kiralama işleminin diğer bir unsuru ise kira bedelinin belirlenmesidir. Kira bedeli kiracının, tanımlanabilir bir varlığın kullanım hakkının elde etmesi karşılığında kiralama süresi boyunca kiraya verene yaptığı ödemelerden oluşmaktadır. Kira ödemeleri sabit veya değişken olabileceği gibi opsiyon içeren kira sözleşmelerinde opsiyon kullanım fiyatı veya kira sonlandırılmasından kaynaklı ceza ödemelerini de içerebilir. Aynı şekilde kalıntı değer taahhütleri kapsamında kiracı tarafindan ödenmesi beklenen tutarlar da bu kapsamda değerlendirilmektedir. Diğer taraftan kira ödemeleri, kiralama konusu olmayan bileşenlere dağıtılan ödemeleri içermez (TFRS 16 Ek A).

a) Değişken kira ödemeleri: Kiralama süresi boyunca varlığın kullanım hakkı için kiracı tarafından kiraya verene yapılan, zamanın geçişi dışında, kiralamanın fiilen başladığı tarihten sonra meydana gelen durum veya şartlardaki değişiklikler nedeniyle değişkenlik gösteren ödemelerdir.

Örnek 3 (illustrative exampledan uyarlanmıştır): A işletmesi satış mă̆azası olarak kullanmak üzere bir mă̆azayı 10 yıllı̆̆ına yıllık 200.000 TL'ye kiralıyor. Kira sözleşmesine göre kira ödemesi her yılın başında yapılacak ve kira ödemeleri her iki yılda ÜFE'ye göre artırılacaktır. Sözleşmede faiz oranı belirtilmemiştir. Kira döneminin başlangıcında ÜFE \% 12, 3.yılın başında \% 14; kiracının alternatif borçlanma faiz oranı \% 12'dir. Kullanım hakkı verilen varlık için doğrusal amortisman yöntemini uygulanacaktır.

Kira döneminin başlangıç tarihinde 1 yıllık kira bedeli nakit olarak ödenmiştir. Kalan dokuz ödemenin \% 12 üzerinden bugünkü değeri 1.065.649,96 TL'dir.

$$
\mathrm{BD}=200.000 /(1+0,12)^{1}+\ldots \ldots \ldots+200.000 /(1+0,12)^{9}
$$

Kiracı varlık ve borçlarını aşağıdaki gibi kayda alır.

\begin{tabular}{|l|l|r|r|}
\hline & & & \\
\hline Kullanım Hakkı Varlık & & 1.265 .650 & \\
\hline & Kira Yükümlülüğü & & 1.065 .650 \\
& Bankalar & & 200.000 \\
\hline
\end{tabular}

1.y1l sonu amortisman gideri: $1.265 .650 \times 0,10$

1.y1l sonu finansman gideri: 1.065 .650 x 0,12

\begin{tabular}{|l|l|r|r|}
\hline & & & \\
\hline Pazarlama Satış ve Dağ. Giderleri & & 126.565 & \\
\hline Finansman Giderleri & & 127.878 & \\
\hline & Birikmiş Amortisman & & 126.565 \\
\hline & Kira Yükümlülüğü & & 127.878 \\
\hline
\end{tabular}

2.yılın başında kiracının kira ödemesi

\begin{tabular}{|l|l|l|r|}
\hline & & & \\
\hline Kira Yükümlülüğ̈̈ & & 200.000 & \\
\hline & Bankalar & & 200.000 \\
\hline
\end{tabular}


2.y1l sonu amortisman gideri: $1.065 .650 \times 0,10$

2.y1l sonu finansman gideri: $((1.065 .650+127.878)-200.000) \times 0,12$

\begin{tabular}{|l|l|r|r|}
\hline & & & \\
\hline Pazarlama Satış ve Dağ. Giderleri & & 126.565 & \\
\hline Finansman Giderleri & & 119.223 & \\
\hline & Birikmiş Amortisman & & 126.565 \\
\hline & Kira Yükümlülüğü & & 119.223 \\
\hline
\end{tabular}

3.yılın başında kira yükümlülüğü: $(993.528+119.223)=1.112 .751$ TL.

3.y1lın kiras1: ( 200.000x14/12) 233.333 TL. gerekmektedir.

3.yılın kira artışından sonra kiracının kira yükümlülüğünü tekrar ölçmesi

$\mathrm{BD}=233.333 /(1+0,12) 1+\ldots \ldots \ldots+233.333 /(1+0,12) 8$

Kalan 8 yıla ait yeni kira bedelinin bugünkü değeri: 1.159.114 TL.

Fark: $1.112 .751-1.159 .460=46.363$ TL.

\begin{tabular}{|l|l|l|l|}
\hline Kullanım Hakkı Varlık & & 46.363 & \\
\hline & Kira Yükümlülüğ̈̈ & & 46.363 \\
\hline
\end{tabular}

3.yılın başında kiracının kira ödemesi

\begin{tabular}{|l|l|l|l|}
\hline Kira Yükümlülüğ̈̈ & & 233.333 & \\
\hline & Bankalar & & 233.333 \\
\hline
\end{tabular}

b) Sabit ödemeler: Kiracı tarafından kiralama süresi boyunca kira konusu varlığı kullanma hakkını elde etme karşılığında kiraya verene yapılan değişken kira ödemeleri dışındaki ödemelerdir.

c) Opsiyona dayalı kira ödemeleri: Kiralama süresine dâhil olmayan, kiralamanın uzatılmasına veya sonlandırılmasına ilişkin bir opsiyonun kapsadığı süre boyunca, kira konusu varlığın kullanım hakkı karşılığında kiracı tarafından kiraya verene yapılacak ödemelerdir.

\subsection{Kiralama Çeşitleri}

Kiralama işlemleri; süresine, finansal raporlara yansımasına, değerine ve üçüncü kişilere yeniden kiralanmasına göre çeşitli şekillerde olabilmektedir:

i. Finansal Kiralama: Dayanak varlığın mülkiyetinden kaynaklanan bütün risk ve getirilerin önemli ölçüde devredildiği kiralamadır.

ii. Faaliyet kiralaması: Dayanak varlığın mülkiyetinden kaynaklanan bütün risk ve getirilerin önemli ölçüde devredilmediği kiralamadır. 
iii. Kısa vadeli kiralama: Kiralamanın fiilen başladığı tarih itibarıyla, kiralama süresi 12 ay veya daha kısa olan kiralamadır. Satın alma opsiyonu içeren bir kiralama kısa vadeli kiralama değildir.

iv. Alt kiralama: Dayanak varlığın, kiracı (alt kiralama kapsamında kiraya veren) tarafından üçüncü bir tarafa yeniden kiraya verilmesi işlemidir; ana kiralama kapsamında kiraya veren ve kiracı arasındaki kiralama ('ana kiralama’) yürürlükte kalmaya devam eder.

v. Dayanak varlığın düşük değerli olduğu kiralamalar:

vi. Sat -Geri kiralama

3. KİRACI AÇISINDAN KİRALAMA ISSTLMLERININ MUHASEBELEŞTIRILMESİ VE RAPORLANMASI

Kiracı, kiralamanın fiilen başladığı tarihte kiralama işleminden doğan kullanım hakkına sahip olduğu varlığı aktifinde ve kiradan doğan borçlarını kira yükümlülüğü olarak pasifte gösterecek şekilde muhasebeleştirir ve finansal tablolarına yansıtır.

\section{1. İlk Muhasebeleştirme}

Kiralama sözleşmesi yapıldıktan sonra kiralamaya konu olan varlık kiracı tarafindan maliyet değeri üzerinden ölçülerek muhasebeleştirilir (TFRS 16 md.23). Varlığın maliyeti belirlenirken kira yükümlülügünün ilk ölçüm tutarı da belirlenmektedir. (TFRS 16 md.26).

Kiralanan varlığın maliyetine aşağıdaki unsurlar eklenmelidir (TFRS 16, md. 24-28):

i. $\quad$ Kira yükümlülüğ̈̈nün ilk ölçüm tarihindeki tutart: $\mathrm{Bu}$ tutar belirlenirken kiralamanın fiilen başladığı tarihte ödenmemiş kira ödemelerinin bugünkü değeri dikkate alınır. Bugünkü değer için, kolaylıkla belirlenebiliyorsa kiralamadaki zimmi faiz oranı, belirlenemiyorsa alternatif borçlanma oranı kullanılır. Kira yükümlülügüne kiralamadan kaynaklı kiracının katlandığı ancak kiraya veren tarafından üstlenilen teşvik alacakları varsa bunların düşülmesinden sonra kalan sabit ödemeler, bir endeks, örneğin tüketici fiyat endeksine veya faiz oranına bağlı olan veya piyasa kira bedellerindeki değişiklikleri yansıtacak şekilde değişken kira ödemeleri, kalıntı değer, kiracı tarafindan kullanacağından makul ölçüde emin olunması durumunda opsiyon kullanım fiyatı ve kiralamanın erken sonlandırılabileceğine yönelik bir opsiyonun kullanılacağına ilişkin ceza ödemeleri dahil edilir.

ii. Başlangıçtaki doğrudan maliyetler: Kiracı tarafından katlanılan bu maliyetler, kira sözleşmesinden dolayı ortaya çıkan, sözleşme yapılmamış olsaydı ortaya çıkmayacak ek maliyetlerdir.

iii. $\quad$ Kiralanan varlı̆̆ın kiralama amacına uygun olarak kullanılmasını sağlamak üzere katlanılacak sökülme, taşınma veya yerleştirilecek alanının restorasyonu ile ilgili maliyetler.

Örnek 4 (illustrative exampledan uyarlanmıştır): Beş yıllık bir süre uzatma imkânı olan bir binanın bir katını 10 yıllı̆̆ına kiralamak üzere bir sözleşme düzenlenmektedir. Kira ödemeleri, başlangıç döneminde ilk on yılda, yıllık 50.000 TL ve kira uzatma opsiyonunun kullandığı beş yıllık dönemde ise yıllık 55.000 TL'dir. Kira ödemeleri her yılbaşında 
yapılacaktır. Kiralamayı elde etmek için kiracı, 20,000 TL'lik başlangıç direkt maliyetine katlanmak durumundadır. Bu tutarın 15,000 TL'lik klsmı, binanın o katında oturan bir önceki kiracının ödemesiyle ilgili, kalanı ise emlakçıya ödenen komisyondur. Kiraya veren kiracıyı kiralama konusunda teşvik etmek için, 5.000 TL'lik gayrimenkul komisyonunu ve kiracı'nın kiralanan yeri iyileştirme için harcayacă̆ 7.000 TL üstlenmeyi kabul etmektedir. Kira döneminin başlangıç tarihinde, kiracı, kiralamayı uzatma seçeneğini kullanmanın makul ölçüde kesin olmadiğl sonucuna varır ve bu nedenle kiralama süresinin 10 yıl olduğunu tespit eder. Kiralamada örtülü olan faiz oranı kolayca belirlenememektedir. Kiracının alternatif borçlanma faiz oranı yıllık \%5 olup bu oran kiralamanın 10 yıllık bir dönem için aynı para birimi cinsinden kiralanan benzer bir varlığın değerine benzer bir tutarl ödünç verebileceği sabit orani yansitan bir orandir.

Çözüm: Kira başlangıç tarihinde (1. 1. 201x), Kiracı ilk y1l için kira ödemesini yapmış, başlangıç direkt maliyetlerini karşılamış ve kira verenden kira teşvikini (komisyon) tahsil etmiştir. Kiralama yükümlülügünü ise kalan dokuz ödemenin bugünkü değerini $\% 5$ üzerinden iskonto ederek 355.391 TL olarak hesaplamıştır.

Kiracı, kira döneminin başında kiralama ile ilişkili varlık ve yükümlülükleri, aşağıdaki şekilde muhasebeleştirir.

\begin{tabular}{|l|l|l|l|}
\hline Kiralanan Varlık & & 405.391 & \\
\hline & Kiralama Yükümlülüğ̈̈ & & 355.391 \\
& Kasa & & 50.000 \\
\hline
\end{tabular}

\begin{tabular}{|l|l|l|l|}
\hline Kiralanan Varlıklar & & 20.000 & \\
\hline & Kasa & & 20.000 \\
\hline
\end{tabular}

\begin{tabular}{|l|l|l|l|}
\hline Kasa & & 5.000 & \\
\hline & Kiralanan Varlıklar & & 5.000 \\
\hline
\end{tabular}

\begin{tabular}{|l|l|l|l|l|l|l|l|l|}
\hline & \multicolumn{9}{|l|}{ Kiralama Borcu } & \multicolumn{3}{l|}{ Kiralanan Varlık } \\
\hline Y11 & $\begin{array}{l}\text { Dönem } \\
\text { Baş1 }\end{array}$ & $\begin{array}{l}\text { Anapara } \\
\text { taksitleri }\end{array}$ & Kalan borç & $\begin{array}{l}\text { Faiz } \\
\text { gideri } \\
(\% 5)\end{array}$ & $\begin{array}{l}\text { Toplam } \\
\text { borç }\end{array}$ & $\begin{array}{l}\text { Dönem } \\
\text { Baş1 }\end{array}$ & $\begin{array}{l}\text { Amortisma } \\
\text { n gideri }\end{array}$ & $\begin{array}{l}\text { Dönem } \\
\text { Sonu }\end{array}$ \\
\hline 1 & 355.391 & - & 355.391 & 17.770 & 373.161 & 420.391 & $(42.039)$ & 378.352 \\
\hline 2 & 373.161 & $(50.000)$ & 323.161 & 16.158 & 339.319 & 378.352 & $(42.039)$ & 336.313 \\
\hline 3 & 339.319 & $(50.000)$ & 289.318 & 14.466 & 303.785 & 336.313 & $(42.039)$ & 294.274 \\
\hline 4 & 303.785 & $(50.000)$ & 253.785 & 12.689 & 266.474 & 294.274 & $(42.039)$ & 252.235 \\
\hline 5 & 266.474 & $(50.000)$ & 216.474 & 10.823 & 227.297 & 252.235 & $(42.039)$ & 210.196 \\
\hline 6 & 227.297 & $(50.000)$ & 177.297 & 8.865 & 186.162 & 210.196 & $(42.039)$ & 168.157 \\
\hline
\end{tabular}

Altıncı yılın sonunda, kiralama dönemindeki değişimi muhasebeleştirmeden önce, kira yükümlülüğü 186.162 TL'dir (50.000 TL'lik dördüncü geri ödemenin bugünkü değeri, yıllık asgari faiz oranına göre iskonto edilmiştir). $8.865 \mathrm{TL}$ faiz gideri 6. yılda kayıtlara alınmaktadır. Maddi duran varlığın kullanıma hazır değeri 168.157 TL'dir. 


\section{2. İzleyen Dönemlerde Değerleme}

Kiracının kiraladığı varlığın, kullanım amacı ve kullanım yeri değerleme yönteminin seçimini etkilemektedir. Kiracı bir varlığı maddi duran varlık veya yatırım amaçlı gayrimenkul niteliğine uygun olarak kullanmak üzere kiralayabilir.

IASB tarafından gerçeğe uygun değerden ölçülen yatırım amaçlı gayrimenkullerin kiralanmasının IFRS 16 kapsamına alınıp alınmaması değerlendirilmiş; yatırım amaçlı gayrimenkullerini kiraya veren işletmelerin IAS 40 çerçevesinde özellikle gerçeğe uygun değer yöntemini uyguladıklarında finansal tablolarının mevcut durumda daha faydalı bilgi sunduğu ifade edilmiştir (Basis for Conclusions, 2016). Sonuç olarak daha önce IAS 17 ve IAS 40' da olduğu gibi IASB, kiraya verenin yatırım amaçlı gayrimenkullerini muhasebeleştirirken IAS 40'1 uygulayacağını, bu varlıklarını kiraya verirken ise IFRS 16'yı uygulanması gerektiğine karar vermiştir. Buna göre, finansal tabloların kullanıcıları, faaliyet kiralamasına konu yatırım amaçlı gayrimenkullere ait gerçeğe uygun değer bilgisini IAS 40'a göre ve kiraya veren tarafından kazanılan kira geliri bilgisini de IFRS 16'ya göre elde edecektir. Böylece IFRS 16 ya göre kiracı kiraladığı varlığı yatırım amaçlı gayrimenkul tanımını karşılayacak şekilde kullanıyorsa yatırım amaçlı gayrimenkuller için uygulanan yöntemleri kullanmalıdır.

Buna göre kiracı yatırım amaçlı gayrimenkullerini gerçeğe uygun değer yöntemini kullanarak ölçüyorsa, yatırım amaçlı gayrimenkul niteliğindeki kiralanan varlığını da gerçeğe uygun değer yöntemini kullanarak ölçmelidir. Aksi takdirde maliyet yöntemini uygular (TFRS 16 md.34).

IASB, kiracının kiraladığı varlığı maddi duran varlık niteliğine uygun şekilde kullanması durumunda dönem sonunda hangi yöntemin uygulanacağına yönelik değerlendirmede de bulunmuştur. Buna göre maddi duran varlıklar gibi parasal olmayan varlıklarına yeniden değerleme modelinin uygulanmasına izin verdiği için aynı kullanım amacıyla kiralanan varlığa da aynı modelin uygulanmasında bir sakınca görmemiştir (Basis for Conclusions, 2016). Bu nedenle kiralanan varlık maddi duran varlık niteliğini karşılayacak şekilde kiralanmış ise ve kiracı maddi duran varlık sınıfına yeniden değerleme modelini uyguluyorsa bu sınıfa uygun kiralanan varlığına da aynı modeli uygulayabilir, aksi takdirde maliyet yöntemi uygulanmalıdır.

Maliyet yöntemine göre, kiralamanın fiilen başladı̆̆ tarihi izleyen dönem sonunda kiralanan varlığın değeri, birikmiş amortisman ve birikmiş değer düşüklüğü zararları düşülerek hesaplanmaktadır. Kira yükümlülüğü ise kiralamanın fiilen başladığı tarihi izleyen dönem sonunda kira ve faiz ödemeleri dikkate alınarak belirlenmektedir.

Kiralama süresindeki her bir döneme ait kira yükümlülüğüne ilişkin faiz, kira yükümlülügünün kalan bakiyesine sabit bir dönemsel faiz oranı uygulanarak bulunan tutardır. Dönemsel faiz oranı, kiralamadaki zımnî faiz oranı olmakla birlikte, bu oranın kolaylıkla belirlenememesi durumunda, kiracının alternatif borçlanma faiz oranı veya uygulanabilir olması durumunda revize edilmiş iskonto oranı olarak belirlenmektedir (TFRS 16 md.36-37). 
Kiralamanın fiilen başladığı tarihten sonra, kiracı kira yükümlülüğüne ilişkin faizi ve dönemdeki kira yükümlülügü ölçümüne dâhil edilmeyen değişken kira ödemelerini, kâr veya zarara yansitır (TFRS 16 md.38).

Kirac1, kiralama süresi veya satın alma opsiyonu ile ilgili bir değişiklik olması durumunda ise kira yükümlülüğünü; yeni kira süresine dayalı olarak revize edilmiş kira ödemeleri ve revize edilmiş iskonto oranı üzerinden indirgeyerek yeniden ölçer (TFRS 16 md 40).

Örnek 5 (illustrative exampledan uyarlanmıştır): Kiralamanın 6. yılında kiracı, A İşletmesi'ni satın alıyor. A İşletmesi başka bir binada bir kat kiralamış olup kiralama sözleşmesi, A Işsletmesi tarafindan kullanılabilir bir fesih seçeneği içermektedir. A Işsletmesi'nin satın alınmasının ardından, kiracı artan işgücünün ihtiyacını karşılayacak bir binada iki kata daha ihtiyaç duymaktadır.

Maliyeti asgariye indirmek için kiracı, aynı binada, başka bir katı 7. yılın sonunda kullanıma hazır olacak şekilde sekiz yıllı̆̆ına kiralar ve 8. yılın başında A İşletmesinin yapmış olduğu kira sözleşmesini sona erdirir.

A İşletmesi'nin edinimi ve A İşletmesi personelinin taşınması, Kiracının kontrolünde olan ve Kiracinın, daha önce kiralama döneminin belirlenmesinde yer almayan uzatma opsiyonunu kullanma konusunda makul olup olmadığı hususunu etkileyen önemli bir olaydır.

Çünkü tüm personelin aynı binada bulunmasının yarattığı fayda daha fazladır ve kiracıyı ek maliyetlerden kurtarmaktadır. Bu nedenle, 6'nc1 yılın sonunda, Kiracı orijinal kiralamasını uzatma opsiyonunu kullanmanın makul olduğu sonucuna varıyor.

\begin{tabular}{|l|l|l|l|l|l|l|l|}
\hline & \multicolumn{4}{|l|}{ Kiralama Borcu } & \multicolumn{3}{l|}{ Kiralanan Varlık } \\
\hline Y11 & $\begin{array}{l}\text { Dönem } \\
\text { Baş1 }\end{array}$ & Kira borcu & $\begin{array}{l}\text { Faiz gideri } \\
(\% 5)\end{array}$ & $\begin{array}{l}\text { Dönem } \\
\text { Sonu }\end{array}$ & $\begin{array}{l}\text { Dönem } \\
\text { Baş1 }\end{array}$ & $\begin{array}{l}\text { Amortisman } \\
\text { gideri }\end{array}$ & $\begin{array}{l}\text { Dönem } \\
\text { Sonu }\end{array}$ \\
\hline 7 & 378.314 & 50.000 & 19.690 & 347.864 & 360.169 & $(40.019)$ & 320.150 \\
\hline 8 & 347.864 & 50.000 & 17.872 & 315.736 & 320.150 & $(40.019)$ & 280.131 \\
\hline 9 & 315.736 & 50.000 & 15.944 & 281,680 & 280.131 & $(40.019)$ & 240.112 \\
\hline 10 & 281.680 & 50.000 & 13.901 & 245.581 & 240.112 & $(40.019)$ & 200.093 \\
\hline 11 & 245.581 & 55.000 & 11.435 & 202.016 & 200.093 & $(40.019)$ & 160.074 \\
\hline 12 & 202.016 & 55.000 & 8.821 & 155.837 & 160.074 & $(40.019)$ & 120.055 \\
\hline 13 & 155.837 & 55.000 & 6.050 & 106.887 & 120.055 & $(40.019)$ & 80.036 \\
\hline 14 & 106.887 & 55.000 & 3.113 & 55.000 & 80.035 & $(40.018)$ & 40.018 \\
\hline 15 & 55.000 & 55.000 & - & - & 40.018 & $(40.018)$ & - \\
\hline
\end{tabular}

Kirac1, dört ödemenin bugünkü değeri olan 50.000 TL tutarındaki kira sözleşmesini ve bunu takiben 55.000 TL olmak üzere beş ödeme yaparak yeniden ölçülür ve bunların hepsi yılda yüzde 6'lık revize edilmiş iskonto oranına göre kaydedilir ki bu 378.174 TL'dir. Kirac1, kira borcunu 192.012 TL arttırır ve bu da 378.174 TL'lik yeniden ölçülen borç ile önceki defter değeri 186.162 TL arasındaki farkı temsil eder. İlgili kullanım, kullanıma ilişkin varlığın ek kullanım hakkının maliyetini yansıtacak şekilde düzeltilir; bu tutar, aşağıdaki gibi muhasebeleştirilir. 


\begin{tabular}{|l|l|l|l|}
\hline Kiralanan Varlık & & 192.012 & \\
\hline & Kiralama Yükümlülüğü & & 192.012 \\
\hline
\end{tabular}

Yeniden değerlemeyi takiben, kiracının kullanım hakkı aktifinin defter değeri 360.169 TL'dir (yani 168.815 TL +192.012 TL). 7. yılın başlangıcından itibaren kiracı, kira borcuna ilişsin faiz giderini yıllık \% 6'lık revize iskonto oranıyla hesaplar.

\subsection{Kiralamanın Yeniden Yapılandırılması}

Kiralamanın yeniden yapılandırılması durumunda, yapılandırma sonucu kiralamanın kapsamını artıran veya azaltan duruma göre ölçme ve muhasebeleştirme farklılık yaratmaktadir.

\subsubsection{Ayrı Bir Kiralama Olarak Muhasebeleștirilen Kiralamalar}

Kiracının mevcut kiralamanın kapsamını genişletmesi ve bu genişlemenin kira bedelinde de bir artışa neden olması durumunda kiralamanın yeniden yapılandırılması gerekmektedir. Bu kiralama şeklinde kiralama süresi ile ilgili bir değişiklik söz konusu değildir. Yeni kiralama mevcut kiralamanın kapsamını genişletmektedir. Bu durumda orijinal kira sözleşmesi değiştirilmektedir (TFRS 16 md.44).

Örnek 6 (illustrative exampledan uyarlanmıştır): Kiracı, 2.000 metrekare ofis alanı için 10 yıllık kiralama işlemine girer. 6. Yıl'ın başında, Kiracı ve Kiralayan, kalan beş yıl için orijinal kira sözleşmesini, aynı binada 3.000 metrekarelik ek ofis alanı dahil etmek üzere değiştirmeyi kabul ediyor. Ek alan, 6. yllın ikinci çeyreğinin sonunda, Kiracı tarafindan kullanılmaya hazır hale getirilir. Kiralamaya yapılan toplam ödemedeki artış, iskonto için düzeltilmiş yeni 3.000 metrekare ofis alanının mevcut piyasa faiz oranı ile orantılıdır bu Kiracı, aynı alanı yeni bir kiracıya kiralarsa (örneğin, pazarlama maliyetleri) Kiralayanın başka türlü masrafa maruz kalmadığını yansıtarak kabul eder.

Kiracı, değişikliği orijinal 10 yıllık kiralamadan ayrı olarak ayrı bir kiralama olarak hesaplar. Bunun nedeni, değişikliğin altında yatan varlığı kullanma konusunda ek bir hakk1 vermesi ve sözleşmenin koşullarını yansıtacak şekilde yeniden kullanım hakkının bağımsız fiyatıyla değiştirilmesi ile finansal kiralama sözleşmesindeki artışın orantılı olmasıdır. Bu örnekte, ek temel varlık, yeni 3.000 metrekare ofis alanını içeriyor. Buna göre, yeni kiralama işleminin başlangıcında (6. yılın ikinci çeyreğinin sonunda), Kiracı, 3.000 metrekarelik büro alanının kiralanmasına ilişkin kullanım hakkı ve kiralama borçlarını muhasebeleştirir. Kiracı, bu değişikliğin sonucu olarak 2.000 metrekarelik ofis alanının orijinal kirasını muhasebeleştirme konusunda herhangi bir düzenleme yapmaz.

\subsubsection{Ayrı Bir Kiralama Olarak Muhasebeleştirilmeyen Kiralamalar}

$\mathrm{Bu}$ kiralama şeklinde mevcut bir kiralamada kira süresinin değiştirilmesine, opsiyonların kullanılması veya kullanılmamasına yönelik değişiklikler söz konusudur. Bu kapsamda kiracı yeniden yapılandırmanın uygulama tarihinde yeni kiralama süresini belirler, yeniden yapılandırılan sözleşmedeki bedeli dağıtır ve revize edilmiş kira ödemelerini revize edilmiş bir iskonto oranıyla indirgeyerek kira yükümlülügünü yeniden ölçer (TFRS 16 md.45). Kira yükümlülügünü yeniden ölçerken kiralamanın kapsamını azaltan yeniden yapılandırmalar için, kullanım hakkı varlığının defter değerini kiralamanın kısmen veya 
tamamen sonlandırılmasını yansıtacak şekilde azaltır. Kiracı, kiralamanın kısmen veya tamamen sonlandırılmasıyla ilgili kazanç ya da kayıpları kâr veya zarara yansıtır (TFRS 16 md.45-46).

Örnek 7 (illustrative exampledan uyarlanmıştır): Kiracı ile kiraya veren arasında 1.1.2017 tarihinde ofis olarak kullanılmak üzere $2000 \mathrm{~m}^{2}$ 'lik bir alanı kira bedeli yılsonunda ödenmek üzere yıllık 100.000 TL'ye kiralama konusunda sözleşme düzenleniyor. Yıllık faiz oranı \% 6'dir. 6.yılın başında kira alanının $1.500 \mathrm{~m}^{2}$ ye çıkarılması buna karşı kira süresinin 8 yıla indirilmesi konusunda orijinal sözleşmede bir değişiklik yapıllyor. Kalan 2 yıl için yeni kira bedeli yıllık 150.000 TL'dir. Yeni borçlanma faiz oranı ise \% 7'dir.

Çözüm: Kiralama alanındaki artış kiradaki artış ile orantılı değildir. Bu nedenle kiracı kiralama alanındaki $1.500 \mathrm{~m}^{2}$ lik artışı ayrı bir kiralama olarak değerlendirmez. Kiralama ile ilgili kira başlangıcında kira yükümlülüğü ve kiralanan varlığa ilişsin bilgiler aşağıdaki gibidir:

\begin{tabular}{|l|l|l|l|l|l|l|l|}
\hline & \multicolumn{3}{|l|}{ Kiralama Yükümlülüğü } & \multicolumn{2}{l}{$\begin{array}{l}\text { Kullanım } \\
\text { Varlık) }\end{array}$} & hakk1 varlık & Kiralanan \\
\hline Y1llar & $\begin{array}{l}\text { Dönem } \\
\text { Baş1 }\end{array}$ & $\begin{array}{l}\text { Faiz } \\
\text { gideri } \\
(\% 6)\end{array}$ & Kira borcu & $\begin{array}{l}\text { Dönem } \\
\text { Sonu }\end{array}$ & $\begin{array}{l}\text { Dönem } \\
\text { Baş1 }\end{array}$ & $\begin{array}{l}\text { Amortisman } \\
\text { gideri }\end{array}$ & $\begin{array}{l}\text { Dönem } \\
\text { Sonu } \\
\text { (net) }\end{array}$ \\
\hline 1 & 736.009 & 44.160 & $(100.000)$ & 680.169 & 736.009 & $(73.601)$ & 662.408 \\
\hline 2 & 680.169 & 40.810 & $(100.000)$ & 620.979 & 662.408 & $(73.601)$ & 588.807 \\
\hline 3 & 620.979 & 37.259 & $(100.000)$ & 558.238 & 588.807 & $(73.601)$ & 515.206 \\
\hline 4 & 558.238 & 33.494 & $(100.000)$ & 491.732 & 515.206 & $(73.601)$ & 441.605 \\
\hline 5 & 491.732 & 29.504 & $(100.000)$ & 421.236 & 441.605 & $(73.601)$ & 368.004 \\
\hline 6 & 421.236 & & & & 368.004 & & \\
\hline
\end{tabular}

10 yılda yıllık 100.000 TL kira ödemesinin \%6 faiz oranından bugünkü değeri: 736.009 TL

Dönem sonu faiz gideri: $736.009 x 0,06=44.160 \mathrm{TL}$

Dönem sonu kira yükümlülügü: 736.009+44.160-100.000 =680.169 TL

\begin{tabular}{|l|l|l|l|}
\hline 31.12.2017 Finansal Durum Tablosu \\
\hline Net Varlık Değeri & 662.408 & Net Yükümlülük & 736.009 \\
Kiralana Varlık Kullanım Hakkı & 736.009 & Kiralama Borcu & 1.000 .000 \\
Birikmiş Amortisman & $(73.601)$ & Kiralama Borç. Mal. & $(263.991)$ \\
\hline
\end{tabular}

\begin{tabular}{|l|r|}
\hline \multicolumn{2}{|l|}{2017 Dönemi K/Z Tablosu } \\
\hline Amortisman Gideri & 73.601 \\
Finansman Gideri & 44.160 \\
\hline
\end{tabular}


Kiralamanın yeniden yapılandırılmasından dolayı kira yükümlülüğünün ve varlığın defter değerinin yeniden hesaplanmas1; kiralanan alan, kira süresi ve iskonto oranındaki değişimin etkisinin dikkate alınması gerekmektedir.

a) Kira yükümlülügünün yeniden hesaplanması: 6. yılın başında yeniden yapılandırmadan önceki tutar 421.236 TL'dir. Yeni sözleşmeye göre kalan üç yıllık kira sözleşmesi, yıllık 150.000 TL'lik ödemeler ve yeni borçlanma oranı yıllık \% 7'yi dikkate alarak kira yükümlülügünü yeniden hesaplanmaktadır. Bu tutar 393.647 TL’dir.

Kira süresinin etkisi: 6.yılın başında orijinal sözleşmeye göre kalan 3 yıl için yıllık 100.000TL'nin \%6 iskonto oranından bugünkü değeri yeniden belirlenerek 267.301TL bulunur. $421.236-267.301=153.935$ TL.

İskonto oranlarındaki değişimin etkisi: Kira yükümlülügünün 6.yılın başında orijinal sözleşmeye göre yıllık 100.000TL.nın kalan 3 yıl için güncellenmiş \%7 iskonto oranından bugünkü değeri 262.431TL. 267.301 - $262.431=4.870 \mathrm{TL}$

Kiralanan alandaki artışın etkisi: $1500 \mathrm{~m}^{2}$ artan alanın 3 y1l için 50.000 TL kira ödemesinin \%7 iskonto oranı üzerinden bugünkü değeri 131.216 TL.

b) Kullanım Hakkı veren Varlığın defter değerinin düzeltilmesi: 6. yılın başında yeniden yapılandırmadan önce, varlığın kullanım hakkı defter değeri 368.044 TL'dir. Yeni sözleşmeye göre kiralama alanı artan $1500 \mathrm{~m} 2$ ile birlikte $3500 \mathrm{~m} 2$ ye çıkmıştır. Orijinal sözleşmeye göre 2000m2lik alana göre kullanım hakkının kalan 3 yıla göre yeniden hesaplanmas1 gerekmektedir. $(368.004 / 5) \times 3=220.802$ TL. Defter değerini düzeltmek için 368.004-220.802 $=147.202 \mathrm{TL}$

\begin{tabular}{|l|l|l|r|}
\hline Kiralama Yükümlülüğü & & 158.805 & \\
\hline & Kiralanan Varlık & & 152.072 \\
& Kazanç & & 6.733 \\
\hline
\end{tabular}

\begin{tabular}{|l|l|l|l|}
\hline Kiralanan Varlık & & 131.216 & \\
\hline & Kiralama Yükümlülüğü & & 131.216 \\
\hline
\end{tabular}

\begin{tabular}{|l|l|l|l|l|l|l|l|}
\hline & \multicolumn{3}{|l|}{ Kiralama Yükümlülüğ̈̈ } & \multicolumn{2}{l|}{$\begin{array}{l}\text { Kullanım } \\
\text { Varlık }\end{array}$} \\
\hline Y1llar & $\begin{array}{l}\text { Dönem } \\
\text { Baş1 }\end{array}$ & Kira borcu & $\begin{array}{l}\text { Faiz gideri } \\
(\% 7)\end{array}$ & $\begin{array}{l}\text { Dönem } \\
\text { Sonu }\end{array}$ & $\begin{array}{l}\text { Dönem } \\
\text { Baş1 }\end{array}$ & $\begin{array}{l}\text { Amortisman } \\
\text { gideri }\end{array}$ & $\begin{array}{l}\text { Dönem } \\
\text { Sonu }\end{array}$ \\
\hline 6 & 393.647 & $(150.000)$ & 27.556 & 271.203 & 347.148 & $(115.716)$ & 231.432 \\
\hline 7 & 271.203 & $(150.000)$ & 18.984 & 140.187 & 231.432 & $(115.716)$ & 115.716 \\
\hline 8 & 140.187 & $(150.000)$ & 9.813 & & 115.716 & $(115.716)$ & \\
\hline
\end{tabular}

\subsection{Kiralama İşleminin Raporlanması} md.47-50):

Kiracı kiralama ile ilgili kalemleri aşağıdaki tablolarda raporlamalıdır(TFRS 16 
i. $\quad$ Finansal durum tablosu: Kullanım hakkı varlıkları ve kira yükümlülükleri

ii. Kâr veya zarar ve diğer kapsamlı gelir tablosu: Kira yükümlülüğüne ilişkin faiz gideri ve kullanım hakkı varlığına ilişkin amortisman gideri

iii. Nakit akış tablosu: Kira yükümlülügünün anapara kısmına ilişkin nakit ödemelerini finansman faaliyetlerinde; kira yükümlülüğünün faiz kısmına ilişkin nakit ödemeleri, kısa vadeli kira ödemeleri, düşük değerli varlıkların kiralamasına ilişkin ödemeler ve kira yükümlülügünün ölçümüne dâhil edilmeyen değişken kira ödemeleri işletme faaliyetlerinde raporlanır.

\section{KIRAYA VEREN AÇISINDAN KIRALAMA IŞLEMLERININ MUHASEBELEŞTIRILILMESI VE RAPORLANMASI}

IAS 17 nin kiraya veren açısından muhasebe gereklilikleri IFRS 16 ya aktarılmıştır (Basis for Conclusions). IFRS 16'da kiraya verenler için muhasebeleştirme gereklilikleri IAS 17'den birçok açıdan değişmemiştir. Dayanak varlığın sahipliğine ait risk ve getirilerin önemli bir kısmını transfer eden kiralamalar finansal kiralamadır. Diğer tüm kiralamalar faaliyet kiralamasıdır. Kiralama işlemleri kiracı ve kiraya veren açısından değerlendirildiğinde kiralama faaliyetinin faaliyet veya finansal kiralama olması kiracı açısından bir fark yaratmamaktadır. Kiraya veren açısından ise kiralama işleminin içeriği ve amacına, dolayısıyla işlemin özüne göre faaliyet veya finansal kiralama olarak sinıflandırılmakta ve buna göre muhasebeleştirme ve raporlama farklılık yaratmaktadır.

Kiraya konu olan bir varlığın mülkiyetinden kaynaklanan bütün risk ve getirilerinin önemli ölçüde devredilmesi halinde finansal kiralama, devredilmemesi halinde ise faaliyet kiralaması söz konusudur (TFRS 16 md.62). Sözü edilen riskler, atıl kapasiteden veya teknolojik eskimelerden kaynaklanan zarar olasılıklarını ve değişen ekonomik koşullar nedeniyle getirilerde oluşabilecek değişiklikleri kapsar. Yararlar ise, varlığın yararlı ekonomik ömrü içerisinde kârlı bir şekilde işletilmesi ve değerinde artış meydana gelmesi sonucunda gelir elde edilmesinin beklenmesi ya da kalıntı değerinin nakde çevrilmesinin beklenmesi şeklinde olabilir. Kiralamanın niteliği kiralama döneminin başında belirlenmekte ve buna göre sınıflandırma yapılmaktadır. Sınıflandırmanın değişebilmesi için kiralamanın yeniden yapılandırılması gerekmektedir.

\subsection{Finansal Kiralama İşlemleri}

Bir kiralama sözleşmesinin de, kiralamanın finansal kiralama olarak nitelendirilebilmesi için aşağıdaki unsurlardan en az birine sahip olması gerekmektedir (TFRS 16 md.63-64):

i. Varlığın mülkiyetinin devredilmenin öngörülmesi: Kiralama sözleşmesinde, kiraya konu olan varlığın mülkiyetinin kiralama süresi sonuna kadar kiracıya devredilmesinin öngörülmesi gerekmektedir. 
ii. Satın alma opsiyonunun bulunması: Kiralama sözleşmesinin başlama tarihinde, kiraya konu varlığın kiralama dönemi sonunda gerçeğe uygun değerinden daha düşük bir fiyattan satın alma seçeneğini kullanacağından makul ölçüde emin olması gerekmektedir.

iii. Kiralama süresinin, varlığın ekonomik ömrünün büyük bir kısmını oluşturması.

iv. Kiralama sözleşmesinin başlama tarihinde kira ödemelerinin bugünkü değerinin varlığın gerçeğe uygun değerine yakın olması.

v. Varlığın kiracı tarafından kullanılabilecek özel bir yapıda olması.

vi. Kiracının kiralamayı feshedebilmesi durumunda, kiraya verenin fesihten kaynaklanan zararlarının kiracı tarafından karşılanması,

vii. Kalıntı değerin gerçeğe uygun değerindeki değişimlerden kaynaklanan kazanç ya da kayıpların kiracıya ait olması.

viii. Kiracının, piyasa fiyatının önemli ölçüde altındaki bir kira bedeli ile ikinci bir dönem için kiralamayı sürdürme hakkının bulunması.

Bununla birlikte kiralanan varlıkla ilgili risk ve getirilerin önemli ölçüde devredilmediğine yönelik açı bir durum varsa bu durumda bu kiralama faaliyet kiralaması olarak nitelendirilmektedir.

\subsection{1. İlk Muhasebeleştirme}

Kiralama sözleşmesi yapıldıktan sonra, kiralamanın fiilen başladığı tarihte kiraya veren, kiralamaya konu olan varlık için hesaplanan net kiralama yatırımına eşit tutarı, alacak hakkı olarak muhasebeleştirir. Başlangıçtaki doğrudan maliyetler, net kiralama yatırımı tutarının ilk ölçümüne dâhil edilir ve kiralama süresi boyunca finansal tablolara yansıtılan gelir tutarını azaltacak şekilde uygulanır (TFRS 16 md.69)

Net kiralama yatırımı, kiralamadaki zımnî faiz oranıyla iskonto edilen brüt kiralama yatırımıdır. Brüt kiralama yatırımı ise finansal kiralama kapsamında kiraya veren tarafından alınacak kira ödemeleri ve kiraya verenin elde edeceği taahhüt edilmemiş kalıntı değerin toplamından oluşmaktadır. Alacak hakkına ait olan tutar, varlığın kiralama süresi boyunca kullanılması nedeniyle henüz tahsil edilmemiş kira alacaklarından oluşmaktadır. Kiracı açısından yapılan ilk muhasebeleştirmedeki kira ödemelerinin belirlenmesi kriteri, kiraya veren açısından da geçerlidir.

\subsection{2. İzleyen Dönemlerde Değerleme}

Kiraya veren, kiralama süresi boyunca hesapladığı faiz gelirini net kiralama yatırımına ilişkin sabit bir dönemsel getiri oranını yansıtan bir esasa göre finansal tablolarına almakta ve bu işlemi gerçekleştirirken kiraya veren kira alacağını, anaparayı ve kazanılmamış faiz gelirini azaltmak üzere brüt kiralama yatırımından düşmektedir.

\subsection{Faaliyet Kiralaması İşlemleri}

Kiraya veren faaliyet kiralaması şeklinde düzenlenen sözleşmeye göre kiraya verdiği varlıktan sağlayacağı kira gelirini doğrusal olarak finansal tablolarına yansıtırken faaliyet kiralamasını elde etmek için katlandığı başlangıçtaki doğrudan maliyetleri dayanak varlığın defter değerine ilave etmekte ve kiralama süresi boyunca kira geliriyle aynı yöntemi kullanarak finansal tablolarına gider olarak yansıtmaktadır. Aynı zamanda kiraya veren ilgili 
varlık için benzer diğer varlıklarına uyguladığı uygun amortisman yöntemini kullanarak amortisman giderini de finansal tablolarına yansitır (TFRS 16 md. 81-84).

\section{SONUÇ VE DEĞERLENDİRME}

TFRS 16’ ya göre bir kira sözleşmesi, kiraya konu varlığın kullanım hakkını ve bu haktan kaynaklı olarak ortaya çıkan ekonomik faydaların belirli bir süre için kiracıya ait olduğunu ortaya koyan bir sözleşmedir. Kiracının belirli bir süre için tanımlanmış bir varlığın kullanımını kontrol etme hakkına sahip olup olmadığını ortaya koyan bir sözleşme olup olmadığını değerlendirmesi gerekmektedir. TFRS 16'da bir sözleşme tanımının koşulları, alınan geri bildirime karşılık olarak TMS 17'ye göre değiştirilmiştir. Ancak, bu değişikliklerin mevcut sözleşmelerin büyük çoğunluğunu etkilemesi beklenmemektedir. Diğer bir ifade ile TMS 17'yi uygulayan bir kiralamanın genel olarak TFRS 16'y1 uygulayan bir kira olması beklenmektedir.

TFRS 16 ile kiracı açısından finansal tablolarda bir kiralama sınıflandırması söz konusu değildir. Kiracı tüm kiralamalarını önceki finansal kiralama uygulaması nasılsa o şeklinde işleme tabi tutacaktır. Buna göre gelecekteki kira ödemelerinin bugünkü değerini kullanım hakkı varlık olarak aktifte, yükümlülüğünü ise pasifte raporlayacaktır. TMS 17 ye göre farklılaşan duruma göre kiracının aktifleştireceği varlık için tek bir ölçü uygulanacaktır. Kiracının varlığı aktifleştirmesi, varlık ve finansal borçlarda artış yaratmasına dolayısıyla işletmenin finansal kaldıraç oranlarında önemli değişikliklere neden olacaktır.

Diğer taraftan kiralanan varlıklar amortismana tabi tutulacaktır. Bu durum da diğer bir özellik olarak karşımıza çıkmaktadır. Kiralamaya konu olan varlık, kiraya verene göre faaliyet kiralaması niteliğinde maddi duran varlık olarak amortisman uygulamasına devam edecek, kiracı ise bu varlığı maddi olmayan duran varlık olarak raporlayıp amortisman yoluyla itfa edecektir. Böylece tek bir varlık için aynı dönemde iki ayrı şirket amortisman hesaplamış olacaktır. Tüm standart uygulamaları dikkate alındığında ilk defa bir varlık için iki kez amortisman hesaplanacaktır.

TFRS 16 kısa vadeli finansal kiralamalar (12 aylık veya daha düşük kiralamalar) ile düşük değerli varlıkların kiralanması durumunda bu tür kiralamalardan kaynaklı yükümlülüklerin dönemsel olarak gider yazılması şeklinde muafiyet de getirmiştir.

TMS17'ye göre kiracının bilanço dışı yükümlülük olarak izlediği faaliyet kiralaması TFRS16 ile finansal kiralama niteliğine dönüşmüş böylece bu kiralamadan kaynaklanan yükümlülüklerin ve kiralamaya konu varlığın aktifleştirilmesi ile gelir tablosuna yansıyan giderlerin niteliği değişmiştir. Buna göre kiracı açısından varlıktan kaynaklanan kira bedeli amortisman gideri ve finansman gideri olarak Kar Zarar Tablosunda raporlanacaktır.

Sonuç olarak TFRS 16 kiraya veren açısından bir değişiklik yaratmamıştır. Kiracı açısından ise önemli değişiklikler getirmiştir. Bu değişiklikler hem finansal durum tablosunu hem de kar zarar tablosunu etkilemiştir. 


\section{KAYNAKLAR}

Acar, Merve - Temiz, Hüseyin- Aktaş, Rafet (2017), "UMS 17 Kiralama İşlemleri Standardından UFRS 16'ya Geçişin Finansal Tablolar Üzerinde Etkisi: Borsa İstanbul Örneği”, Muhasebe Bilim Dünyası Dergisi, Cilt 19, Sayı 3, ss. 592-623.

Akbulut, Destan Halit (2018), "Faaliyet Kiralaması İşlemlerinin Aktifleştirilmesinin Finansal Tablolara Ve Finansal Oranlara Etkisi Üzerine Bir Telekomunikasyon Şirketinin Vak’a İncelemesi” Muhasebe ve Finansman Dergisi, sayı 78, ss.17-36.

Aktaş, Rabia-Karğın, Sibel - Demirel Arıcı, Nuray (2017)“'Yeni Kiralamalar Standardı UFRS 16'nın Getirdiği Yenilikler ve İşletmelerin Finansal Tablolarına ve Finansal Oranlarına Olası Etkilerinin Değerlendirilmesi”, İktisadi Araştırmalar Dergisi, DOI:10.20491/isarder.2017.362, ss. 858-881.

Aslan, Ümmühan (2018), “UFRS 16 Kiralamalar Standardı Kapsamında Faaliyet Kiralamasının Kiracı İşletme Tarafından Muhasebeleştirilmesi ve Raporlanması", $\quad$ Muhasebe ve Finansman Dergisi, say1 77, ss.55-68.

BDO Global (2017), IFRS in Practice IFRS 16 Leases, BDO IFR Advisory Limited, UK.

Czajor, Przemysław-Michalak, Marcin (2017), “Operating Lease Capitalization-Reasons and its Impact on Financial Ratios of WIG30 and sWIG80 Companies”, Practical and Theoretical Issues in Contemporary Financial Management, pp. 23-36.

Deloitte (2016), Leases, A Guide to IFRS 16, Deloitte Touche Tohmatsu Limited, London.

IASB. Illustrative Examples, International Financial Reporting Standard, International Financial Reporting StandardFoundation, London, January 2016.

FASB (2016), Lease-Accounting-Handbook, https://explore.leaseaccelerator.com/wpcontent/uploads/2016/04/FASB-Lease-Accounting-Handbook-2016.pdf

IASB (2016), Basis for Conclusions, International Financial Reporting Standard, International Financial Reporting Standard Foundation, London, January 2016.

IFRS (2016), Effects Analysis, IFRS 16 Leases, International Financial Reporting Standard Foundation, London.

IFRS (2016), Project Summary and Feedback Statement, IFRS 16 Leases, January.

José Morales-Díaz-Constancio Zamora-Ramírez (2018), “The Impact of IFRS 16 on Key Financial Ratios: A New Methodological Approach”, Journal Accounting in Europevol.15, issue 1, pp.105-133.

Joubert, Michelle- Garvie, Leanda- Parle, Gabrielle (2017), “Implications of the New Accounting Standard for Leases AASB 16 (IFRS 16) with the Inclusion of 
Operating Leases in the Balance Sheet”, Journal of New Business Ideas \& Trends, Cilt 15, Sayı 2, pp. 1-11.

KGK (2018), TFRS 16, www.kgk.gov.tr, 16 Nisan 2018 tarihli ve 29826 sayılı Resmi Gazete.

KPMG (2016). IFRS 16 Leases, A More Transparent Balance Sheet, First Impressions IFRS, KPMG. https:/home.kpmg.com/content/dam/kpmg/pdf/2016/06/SlideSharepresent-O-1601-04.pdf

Öztürk, Can (2016), “UFRS 16 Kiralama İşlemleri Standardının Eski UMS 17 Standardı İle Karşılaştırılması Ve Almanya Ve Türkiye'de Hisse Senetleri Halka Açık Olan Hava Yolu Şirketlerinin Finansal Durumuna Etkisi”, Muhasebe Bilim Dünyası Dergisi, $\quad$ Cilt 18, Sayı 1, ss. 1-50.

Sharlene Wilson (2016), KPMG Ignite, 2016, https://home.kpmg.com/content/dam/kpmg/pdf/2016/05/11753-KPMG-IgniteBrochure-Final-v4-Secured.pdf 